\title{
Systematic large-scale meta-analysis identifies a panel of two mRNAs as blood biomarkers for colorectal cancer detection
}

\author{
Maria Teresa Rodia ${ }^{1,2}$, Giampaolo Ugolini ${ }^{3}$, Gabriella Mattei ${ }^{1,2}$, Isacco Montroni ${ }^{3}$, \\ Davide Zattoni ${ }^{3}$, Federico Ghignone ${ }^{3}$, Giacomo Veronese ${ }^{3}$, Giorgia Marisi ${ }^{4}$, Mattia \\ Lauriola $^{1,2}$, Pierluigi Strippoli ${ }^{1,2,5}$, Rossella Solmi ${ }^{1,2}$ \\ ${ }^{1}$ Department of Experimental, Diagnostic and Specialty Medicine (DIMES), Unit of Histology, Embryology and Applied Biology, \\ University of Bologna, Bologna, Italy \\ ${ }^{2}$ Centre of Molecular Genetics, "CARISBO Foundation", Bologna, Italy \\ ${ }^{3}$ Department of Medical and Surgical Sciences (DIMEC), University of Bologna, Bologna, Italy \\ ${ }^{4}$ Biosciences Laboratory, Istituto Scientifico Romagnolo per lo Studio e la Cura dei Tumori (IRST) IRCSS, Meldola, Italy \\ ${ }^{5}$ Interdepartmental Center for Cancer Research "Giorgio Prodi" (CIRC), S. Orsola-Malpighi Hospital, University of Bologna, \\ Bologna, Italy \\ Correspondence to: Mattia Lauriola, e-mail: mattia.lauriola2@unibo.it \\ Pierluigi Strippoli, e-mail: pierluigi.strippoli@unibo.it \\ Keywords: TRAM: Transcriptome Mapper, CRC: colorectal Cancer, CTC: circulating tumour cells \\ Received: August 11, 2015 \\ Accepted: February 28, 2016 \\ Published: March 16, 2016
}

\section{ABSTRACT}

Colorectal cancer (CRC) is the third most common cancer in the world. A significant survival rate is achieved if it is detected at an early stage. A whole blood screening test, without any attempt to isolate blood fractions, could be an important tool to improve early detection of colorectal cancer. We searched for candidate markers with a novel approach based on the Transcriptome Mapper (TRAM), aimed at identifying specific RNAs with the highest differential expression ratio between colorectal cancer tissue and normal blood samples. This tool permits a large-scale systematic metaanalysis of all available data obtained by microarray experiments. The targeting of RNA took into consideration that tumour phenotypic variation is associated with changes in the mRNA levels of genes regulating or affecting this variation.

A real time quantitative reverse transcription polymerase chain reaction (qRT-PCR) was applied to the validation of candidate markers in the blood of 67 patients and 67 healthy controls. The expression of genes: TSPAN8, LGALS4, COL1A2 and CEACAM6 resulted as being statistically different.

In particular ROC curves attested for TSPAN8 an AUC of 0.751 with a sensitivity of $\mathbf{8 3 . 6} \%$ and a specificity of $58.2 \%$ at a cut off of 10.85 , while the panel of the two best genes showed an AUC of 0.861 and a sensitivity of $92.5 \%$ with a specificity of $67.2 \%$.

Our preliminary study on a total of 134 subjects showed promising results for a blood screening test to be validated in a larger cohort with the staging stratification and in patients with other gastrointestinal diseases.

\section{BACKGROUND}

Colorectal cancer (CRC) is the third most common cancer in the world, with nearly 1.4 million new cases detected in 2012. A significant survival rate is achieved if the primary tumour is detected at an early stage [1-3].

Most CRC develops in a multistep process, starting with benign precancerous adenomas, which develop into aggressive metastatic carcinoma [4]. This makes early detection crucial to benefit the chances of a positive outcome for CRC patients [5].

Multiple non-invasive screening modalities have been investigated including faecal tests that detect the presence of haemoglobin or blood in the stools [5-7], and improved faecal test methods that add an integral DNA extraction [8]. Very recently, Imperiale at al. [9] proposed a multi-target stool DNA test, Cologuard (Exact Sciences Corporation, Madison WI), approved by the 
American Food and Drug Administration (FDA), but further adjustments are necessary because of the high rate of false positive stool DNA results [10]. Moreover, in 2010, the CellSearchVR system (Veridex, JohnsonJohnson,USA) for circulating tumour cell (CTC) enumeration in metastatic colorectal cancer (mCRC), based on immunofluorescent detection, received FDA approval $[11,12]$. Recently, a combinatorial panel of seven mRNA biomarkers in blood: annexin A3 (ANXA3), C-Type Lectin Domain Family 4, Member D (CLEC4D), Lamin B1 (LMNB1), Proline Rich Gla (G-Carboxyglutamic Acid) 4 (Transmembrane) (PRRG4), Tumor Necrosis Factor, Alpha-Induced Protein 6 (TNFAIPO), Vanin 1 (VNN1) and Interleukin 2 Receptor, Beta (IL2RB) has been proposed by Marshall et al. [13] (ColonSentry ${ }^{\circledR}$, Canada - Enzo Biochem. USA). The test has recently been approved by the New York State Department of Health as a test to determine a person's risk of having CRC [14]. The search for markers as a screening tool in the patientss blood represents an active field of research for early detection of colorectal cancer. Numerous reports include coding mRNAs, microRNAs (miRNAs), protein, metabolic, DNA mutation [15] and methylation markers. Currently, the principal trends of research into mRNA candidate markers generally involve several types of experimental evidence: circulating tumour cells (CTCs) [13,16], cancer stem cells (CSCs) [17] and circulating free RNA (cfRNA) [18]. The metastatic spread occurs very early in the tumourss development; hence specific and sensitive detection of CTCs has become crucial for diagnosis [19]. A quantitative polymerase chain reaction (qPCR) has recently been described as a good CTC quantification method [19-22].

The cfRNAs could be good blood cancer biomarkers, as they may be more informative, specific and accurate than protein biomarkers [23-26]. Various research groups have investigated the potential use of circulating mRNA as markers for cancer. The general experimental strategy is to employ microarray technology for mRNA expression profiling, which is followed by a real time quantitative reverse transcription polymerase chain reaction (qRT-PCR) validation. The specimens used are either mRNA extracted directly from blood, serum/ plasma or from isolated blood cells [6].

Our research, as well as that of other groups, argues that a test on the whole blood, without any attempt to isolate CTCs or CSCs or any blood fraction, is much simpler to conduct (in the perspective of a wide use in oncology practice), and is not affected by loss of CTCs or CSCs, whose number is critical for the success of the test, during purification [27]. The targeting of RNA makes use of the fact that tumour phenotypic variation is associated with changes in the mRNA levels of genes regulating or affecting this variation. This has led to the widespread use of a qRT-PCR assay in clinical diagnostics [28]. RT-PCR offers several advantages over other detection methods in terms of high sensitivity and specificity. To date, the main issue has been to identify a biologically suitable mRNA with a clear cut-off of its expression values between $\mathrm{CRC}$ and healthy subjects. We have previously addressed this question by exploiting pre-built online databases of differential expression among tissues or by performing ad hoc microarray experiments, which compare cancer patients' blood with healthy reference subjects [29-33]. However, to our knowledge, no study has to date been designed which undertakes a comprehensive, systematic analysis of gene expression in CRC and blood while addressing three major problematic issues: including the largest possible number of available gene expression profile datasets from different sources, integrating the data at level of each transcribed known or uncharacterized locus by uniform gene name assignment, and performing robust intra-sample and inter-sample normalization.

We used a novel approach based on the Transcriptome Mapper (TRAM) [34-36] tool, aimed at identifying specific RNAs [37] with the highest differential expression ratio between CRC and normal blood samples, and therefore possibly suitable for detection of CRCrelated changes in patients' blood. TRAM is based on a systematic large-scale meta-analysis of all available data obtained by microarray experiments.

The best candidate RNAs identified by our computational biology approach out of 38,104 human transcripts whose expression level was compared between CRC $(n=349)$ and blood $(n=200)$ samples, were tested by a quantitative RT-PCR analysis. A group of 134 healthy volunteers and patients with diagnosed $\mathrm{CRC}$ at various stages was used.

\section{RESULTS}

\section{TRAM based data set meta-analysis}

A systematic meta-analysis of differential gene expression in CRC and normal blood was conducted to identify the mRNAs with the highest expression ratio between CRC and blood, in order to select the best candidate biomarkers. The Transcriptome Mapper (TRAM) tool allowed the management of experimental platforms with different numbers of genes in order to maximize information that could be extracted from the dataset [34]. Following a comprehensive search, a total of 37 GEO Series were selected for CRC along with an additional 23 series for blood. The selected series included a total of 2,532 and 958 samples, respectively. Random sampling was done to further select the first 10 listed samples for each series including more than 10 samples, thereby reducing the number of samples analysed to 349 for CRC and 200 for blood (14\% and $21 \%$ of the total, respectively; Supplementary Table 1). Analysis of the final resulting integrated and normalized dataset allowed the identification of genes, among a total of 38,104 expressed loci with an available expression value in both 'A' (CRC) and 'B' (blood) pools, with the absolute greatest ' $\mathrm{A} / \mathrm{B}$ ' ratio between expression value in $\mathrm{CRC}$ 
tissue vs blood cells. The list (Supplementary Table 2) comprises CRC overexpressed loci with a ratio greater than 32:1, which could be considered as a threshold for the choice of the best candidate RNAs. In this case, a clearly identifiable difference equivalent to 5 cycles of PCR, in theory, is expected between cases and controls during the exponential phase of amplification.

\section{CRC marker selection}

A further screening of the complete TRAM database results (Supplementary Table 2) was carried out, in order to search for loci whose mean expression value came from a number of data points greater than $50 \%$ of the sample number for each pool, i.e. $>175$ for $\mathrm{CRC}$ and $>100$ for blood. In this way, transcripts whose mean expression value was not assessed in a large fraction of the sample pool were excluded from the experimental validation. This was often the case of uncharacterized UniGene expressed sequence clusters coded by the "Hs." prefix. This filtering led to the selection of the 15 best theoretical candidates (Table 1).

In order to select for transcripts with absolute high abundance, considering that the expression value is expressed as a percentage of the mean value in the integrated expression profile (i.e., $1,000=$ ten times the mean), we further excluded the last loci of the list (from SLC26A3 to KRT20) except CEACAM6, which has a high absolute expression value. We then excluded carcinoembryonic antigen-related cell adhesion molecule 5 (CEACAM5), collagen, type III, alpha 1 (COL3A1), and Keratin 18 (KRT18) because of the existence of pseudogenes, which not allow mRNA specific PCR primer design, to distinguish between mRNA and DNA contamination. Hence the seven final candidate markers left for further evaluation were: Tetraspanin 8 (TSPAN8), Epithelial Cell Adhesion Molecule (EPCAM), Serine Peptidase Inhibitor, Kazal Type 1 (SPINK1), Collagen, Type I, Alpha 2 (COL1A2), Cadherin 1, Type 1, E-Cadherin (Epithelial) $(\mathrm{CDH})$, Lectin, GalactosideBinding, Soluble, 4 (LGALS4), and Carcinoembryonic Antigen-Related Cell Adhesion Molecule 6 (Non-Specific Cross Reacting Antigen) (CEACAM6) (Table 1).

\section{Quantitative analysis of blood mRNA markers}

Each RNA sample (patients or healthy) was tested for quality and the expression of the listed candidate markers was detected by quantitative PCR and normalized on the housekeeping gene $B 2 M$ as reported by Hamm et al. [38]. In the same data sets (CRC and blood tissues), which we employed in our meta-analysis (Supplementary Table 2), $B 2 M$ displayed the lowest variability between $\mathrm{CRC}$ and normal groups (calculated as Standard Deviation compared to the Mean), being the most stably expressed gene in comparison with other most commonly used reference housekeeping genes such as $A C T B$ and $G A P D H$.
The standard curve of each primers pair, along with the slope values, is shown in Supplementary Figure 1 and Supplementary Table 3.

The tested genes showed a unique peak in melting curve analysis and none of the negative controls gave detectable amplification values, corroborating the specific amplification.

The normalized mRNA expression levels in blood, indicated as Delta CT (Threshold Cycle) were reported in Table 2. Following a first round of analysis testing 39 CRC and 36 normal samples, the four best identified markers were tested in the complete sample set (Table 2). The relative expression level of the candidate markers appears to be extremely specific for these genes. The expression of four of the seven analysed genes: TSPAN8, LGALS4, COL1A2 and CEACAM6, displayed statistically significant differences between cases and controls.

\section{Diagnostic value of blood mRNA markers for CRC}

In order to evaluate the diagnostic accuracy in term of specificity and sensitivity of the candidate markers, the Receiver Operating Characteristic (ROC) curve analysis was applied. Specifically, the analysis of individual markers was performed by using the MedCalc software. This tool performs statistical test that allows the user to obtain ROC data sensitivity, specificity, and the Youden index (which provides the threshold value that minimizes the probability of finding false positives and false negatives), in order to determine a cutoff for each marker, as reported in Table 2. An initial training/validation test was performed for TSPAN8, by blindly dividing the samples cohort into two subgroups: the first one serving as training, the second as validation set (as reported in Supplementary Figure 2C). The test returned a good match for the two subsets, but due to the still relatively small cohort tested, we constructed the further ROC curves, without any stratification of the samples.

Once the best markers according to ROC analysis has been selected, we integrated the 4 candidate markers values (TSPAN8, LGALS4, COL1A2 and CEACAM6), into one variable via Discriminate Analysis by using SPSS. More specifically, the SPSS tool calculated the discriminating power of the simultaneous use of the best scores obtained with MedCalc. Hence, we built a model of multiple logistic (binary logistic regression). In this model the dependent variable is the presence/ absence of the disease (normal Vs cancer) and the independent variable is the circulating level of markers used to construct the ROC curve, creating a graph of probability. Through this analysis, we examined whether using a panel of biomarkers as opposed to using them individually improves their discriminating power. The highest diagnostic accuracies closest to 1 were found for TSPAN8 (AUC 0.751), LGALS4 (AUC 0.746), 
Table 1: Selected candidate markers (the first 15 loci with the highest ' $A / B$ ' ratio and with a number of data points greater than $50 \%$ of the sample number for each pool)

\begin{tabular}{|c|c|c|c|c|c|c|c|c|}
\hline Gene name & $\begin{array}{c}\text { Value 'A' } \\
\text { Colorectal } \\
\text { cancer }\end{array}$ & $\begin{array}{c}\text { Value 'B' } \\
\text { Normal } \\
\text { blood }\end{array}$ & $\begin{array}{l}\text { Ratio } \\
\text { 'A/B' }\end{array}$ & Location & $\begin{array}{c}\text { Data } \\
\text { points } \\
\text { 'A' }\end{array}$ & $\begin{array}{c}\text { Data } \\
\text { points } \\
\text { 'B' }\end{array}$ & $\begin{array}{c}\text { SD as \% of } \\
\text { expression } \\
\text { 'A' }\end{array}$ & $\begin{array}{c}\text { SD as \% of } \\
\text { expression } \\
\text { 'B' }\end{array}$ \\
\hline TSPAN8 & $2,313.03$ & 13.12 & 176.36 & $\operatorname{chr} 12$ & 349 & 185 & 67.66 & 424.15 \\
\hline EPCAM & $2,111.87$ & 13.60 & 155.27 & chr2 & 354 & 222 & 69.86 & 82.81 \\
\hline SPINK1 & $1,086.88$ & 12.68 & 85.70 & chr5 & 368 & 215 & 99.51 & 107.87 \\
\hline COL3A1 & 862.27 & 10.10 & 85.35 & chr2 & 1291 & 527 & 140.54 & 110.39 \\
\hline CEACAM5 & $2,074.89$ & 24.44 & 84.88 & chr19 & 572 & 315 & 132.13 & 144.57 \\
\hline COL1A2 & 989.85 & 12.79 & 77.42 & chr7 & 767 & 549 & 115.82 & 131.00 \\
\hline CDH1 & 825.52 & 11.87 & 69.56 & chr16 & 573 & 455 & 120.84 & 105.73 \\
\hline$L G A L S 4$ & $1,980.67$ & 29.50 & 67.15 & $\operatorname{chr} 19$ & 369 & 185 & 77.43 & 104.96 \\
\hline KRT18 & $1,719.60$ & 25.69 & 66.93 & $\operatorname{chr} 12$ & 482 & 318 & 88.43 & 111.69 \\
\hline SLC26A3 & 800.45 & 12.31 & 65.01 & chr7 & 369 & 195 & 187.48 & 138.12 \\
\hline REG1A & 776.24 & 12.54 & 61.91 & chr2 & 346 & 185 & 191.25 & 75.25 \\
\hline FN1 & 664.80 & 11.22 & 59.25 & chr2 & 1588 & 902 & 144.43 & 125.93 \\
\hline LUM & 556.84 & 9.40 & 59.22 & chr12 & 403 & 262 & 108.62 & 83.50 \\
\hline CEACAM6 & $2,245.12$ & 38.49 & 58.33 & chr19 & 583 & 274 & 65.15 & 480.79 \\
\hline KRT20 & 731.52 & 12.58 & 58.13 & $\operatorname{chr} 17$ & 372 & 182 & 119.91 & 85.52 \\
\hline
\end{tabular}

Colorectal cancer tissue ('A'), normal blood ('B').

'Value': mean gene expression value normalized across all the pool samples; 'Data points': number of spots with an expression value for the locus; 'SD': standard deviation for the expression value expressed as a percentage of the mean. Gene name in bold: selected for experimental validation.

Table 2: mRNAs expression levels of the indicated markers

\begin{tabular}{|c|c|c|c|c|c|c|c|}
\hline $\begin{array}{c}\text { CRC } \\
\text { patients } \\
\text { number } \\
(n)\end{array}$ & $\begin{array}{c}\text { CRC patients } \\
\text { Mean } \\
\Delta \mathrm{Ct} \pm \mathrm{SD}\end{array}$ & $\begin{array}{l}\text { Controls } \\
\text { number }\end{array}$ & $\begin{array}{c}\text { Controls } \\
\text { Mean } \\
\Delta \mathrm{Ct} \pm \mathrm{SD}\end{array}$ & $p$-value & AUC & $\begin{array}{c}\text { Sensitivity } \\
\%\end{array}$ & $\begin{array}{c}\text { Specificity } \\
\%\end{array}$ \\
\hline
\end{tabular}

\begin{tabular}{|c|c|c|c|c|c|c|c|c|}
\hline TSPAN8 & 67 & $9.41 \pm 2.00$ & 67 & $11.33 \pm 1.72$ & 0.00000002 & 0.751 & 83.6 & 58.2 \\
\hline EPCAM & 39 & $11.23 \pm 1.36$ & 36 & $11.83 \pm 1.23$ & 0.08 & 0.631 & - & - \\
\hline SPINK 1 & 39 & $11.88 \pm 2.87$ & 36 & $11.85 \pm 2.59$ & 0.9 & 0.503 & - & - \\
\hline COL1A2 & 67 & $9.59 \pm 2.14$ & 67 & $11.45 \pm 1.92$ & 0.0000005 & 0.718 & 73.1 & 59.7 \\
\hline $\mathrm{CDH1}$ & 39 & $9.9 \pm 0.9$ & 36 & $9.5 \pm 1.08$ & 0.2 & 0.581 & - & - \\
\hline LGALS4 & 67 & $14.43 \pm 1.28$ & 67 & $12.89 \pm 1.97$ & 0.0000004 & 0.746 & 82.1 & 61.2 \\
\hline CEACAM6 & 67 & $13.23 \pm 1.24$ & 67 & $12.34 \pm 1.89$ & 0.0017 & 0.632 & 65.7 & 61.2 \\
\hline $\begin{array}{l}\text { Panel: } \\
\text { TSPAN8 + } \\
\text { LGALS4 }\end{array}$ & 67 & - & 67 & - & & 0.861 & 92.54 & 67.16 \\
\hline
\end{tabular}

Statistical values between CRC patients and controls, AUC from ROC curves, sensitivities, specificities are reported 'CRC': colorectal cancer; ' $\triangle \mathrm{Ct}$ '): delta cycle threshold; 'Ct': threshold cycle; 'SD': standard deviation; 'AUC': area under the ROC curve. $p$-value: 2-way Anova. 
COL1A2 (AUC 0.718) and CEACAM6 (AUC 0.632). The corresponding graphical elaboration for each marker is reported in Figure 1.

\section{Assessing diagnostic potential of the mRNA panel}

To assess the potential use of the selected mRNA candidates as a diagnostic panel for CRC, ROC analysis was performed on the validated data set for every possible combination. TSPAN8 and COL1A2 combination displayed $68.7 \%$ sensitivity and $73.1 \%$ specificity (Figure $2 \mathrm{~A}$ ). The combination of LGALS4 and TSPAN8 displayed 67.16\% specificity and $92.54 \%$ sensitivity (Figure $2 \mathrm{~B}$ ), with a positive predicted value (ppv) of $76.25 \%$ and negative predicted values (npv) of $88.25 \%$, as reported in Supplementary
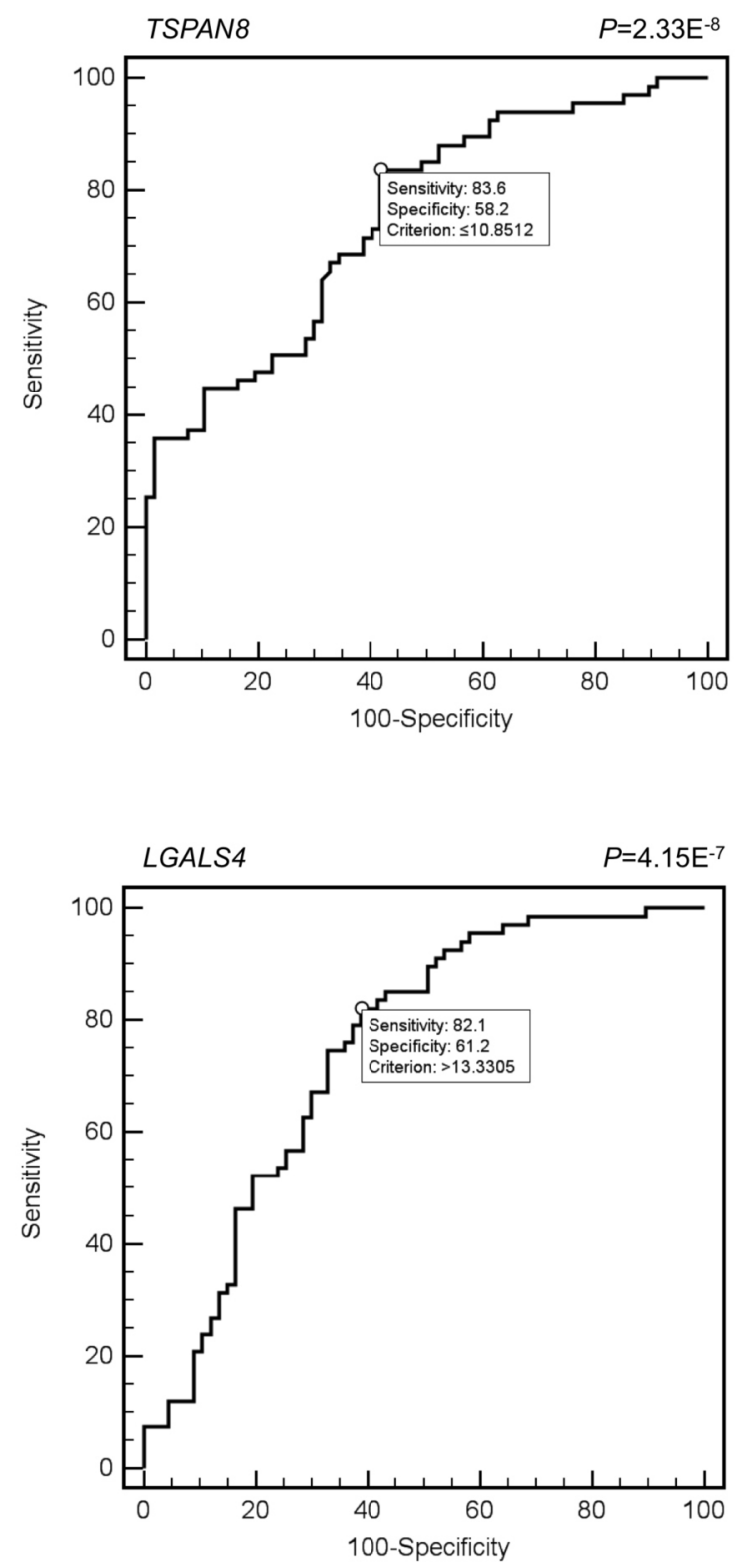

Table 4. For the single genes, specificity reached about $61 \%$ and $58.2 \%$ respectively, while sensitivity measured $82.1 \%$ and $83.6 \%$ respectively. The combination of TSPAN8 with LGALS4 and COL1A2 returned the same sensitivity and specificity as TSPAN8 and LGALS4 combination (Figure 2C).

\section{DISCUSSION}

A whole blood screening test could be an important addition to improving CRC screening and early cancer detection. We searched for the candidate markers with the TRAM software application, which executed the basic computational biology tasks needed for this study. TRAM is a powerful bioinformatics tool, which allowed the complete comparison of differential gene expression between colon cancer and normal blood tissues without
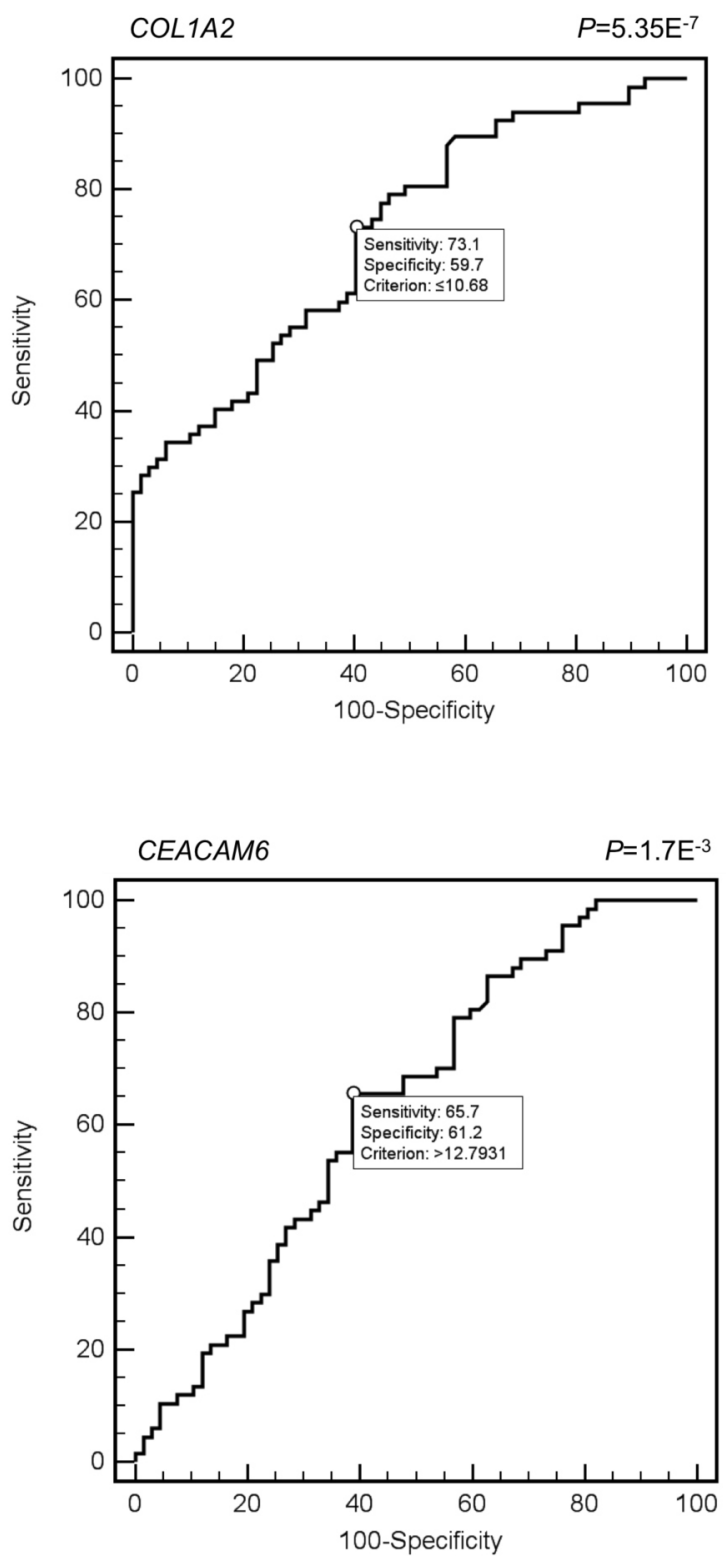

Figure 1: ROC curves of TSPAN8, LGALS4, COL1A2 and CEACAMG. 
any a priori knowledge. It also allowed us to parse, integrate and analyse gene expression data relative to all the described human RNAs. Notably the bioinformatics analysis blindly detected some genes that are already known as markers in solid carcinomas. Furthermore, by using the whole blood as a detection tool, without any attempt to fractionate, we were able to test both mRNA molecules and circulating free RNAs. The latter molecules have been described in the blood of CRC patients as reflecting the circulating tumour burden [23]. These molecules are stable in the bloodstream with a variable half-life ranging from 15 minutes to several hours [37, 39-40]. In our study, we assumed to detect any RNA molecules of either cfRNA or CTCs origin. Under these conditions our analysis confirmed four out of the seven candidate markers as potential CRC blood markers. The expression of these genes: TSPAN8, LGALS4, COL1A2 and $C E A C A M 6$ in the whole blood may be useful in the detection of CRC.

The combination of TSPAN8 and LGALS4 shows promising values of sensitivity $(92.5 \%)$ and specificity $(67.16 \%)$, competing with the widely used faecal occult blood test (FOBT), or the faecal immunochemical test (FIT) (74\% and 95\%) and Cologuard (92\% and 87\%) $[8,41]$. To our knowledge, this is the first report examining TSPAN8 mRNA expression in the blood for CRC diagnosis.
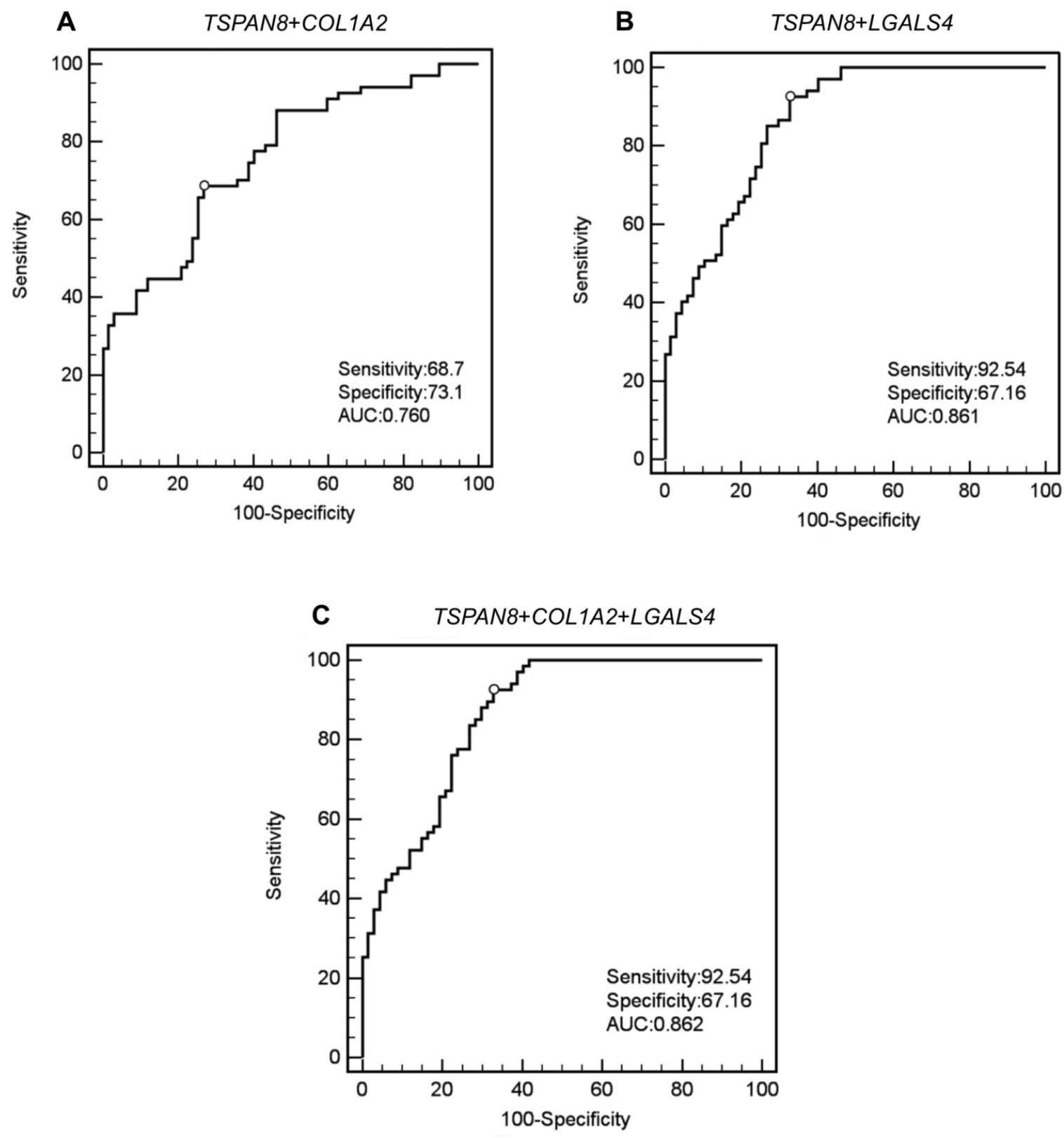

Figure 2: ROC curves of panels of the indicated marker gene combinations. (A) TSPAN8 + COL1A2; (B) TSPAN8+LGALS4; (C) TSPAN8+COL1A2+LGALS4. 
Little is known about TSPAN8 or Co-029 protein in cancer. Previous studies described this protein as an invasive marker that enables melanoma cells to cross the basement membrane, leading to dermal invasion and progression to metastasis. Hence TSPAN8 was suggested a promising target in early detection, at least in melanoma [42].

The others markers screened include cell surface glicoproteins such as CEACAM6 [43-44] and stromal genes such as COL1A2 and LGALS4. The latter regulates cell motility on collagen I by cooperating with the E-cadherin/p120-catenin (p120ctn) complex. COL1A2, the most abundant protein in the human body, indeed increases the synthesis in colon malignancy and reveals a considerably higher expression in stage II tumours, suggesting that its activation is an early event in CRC tumorigenesis $[45,46]$. In our study, TSPAN8 as well as COL1A2 expression is significantly lower in the blood of healthy subjects compared to patients. On the contrary, the expression level of the two other candidate markers LGALS4 and CEACAM6 display opposite trends, with higher levels in normal healthy blood compared to cancer blood. These results find support in the literature, which shows, at least for $L G A L S 4$, associated high expression in the normal small intestine, colon, and rectum, while in colorectal cancers conditions the expression levels fall. Hence it was suggested that it functions as a tumour suppressor by inhibiting cell proliferation. Furthermore, decreased LGALS4 mRNA levels may be an early event in colon carcinogenesis [47]. We argue that products whose expression in colon cancer is very different from that in normal mucosa are potential biological markers of the progression of malignant lesions [48].

Interestingly, by combining TSPAN8 and LGALS4, which display specular expression in cancer and/or normal blood (TSPAN8 is higher in CRC blood, whereas LGALS4 is lower), we detected promising values of sensitivity and specificity compared to the markers alone. The TSPAN8 and $C O L 1 A 2$ combination displays an improvement in specificity increasing to $73.1 \%$.

Undoubtedly, our results require extending the study to a larger cohort, which might also allow the staging stratification and the inclusion of patients with other gastrointestinal diseases. It would also be interesting to verify whether the staging and tumour invasiveness display a different amount of the panel markers. So far our results suggest that a panel, reflecting the heterogeneity of the disease, is more successful at diagnosing CRC than a single biomarker [7, 49]. Both stromal genes and cancer membrane glycoprotein appeared to be useful contributions to the cancer gene expression profile. Indeed, interactions between the stroma and parenchyma of tumours are increasingly recognized as important factors in tumour biology and clinical outcome [50, 51].

In summary, our preliminary study showed that the TSPAN8, LGALS4 and COL1A2 mRNA expression in blood is a reliable tool for detecting the presence of
CRC, considering the levels of sensitivity and specificity evidenced. Further studies will be needed to test the panel of biomarkers in the screening setting, where the detection of early cancers or precancerous lesions is a crucial target. Both preneoplastic lesions and high-risk adenoma patients should be questioned in future studies, in order to test these markers in the context of early detection.

\section{MATERIALS AND METHODS}

\section{Database search and selection}

The Gene Expression Omnibus (GEO) functional genomics repository was searched for: "Colorectal cancer AND Homo sapiens [ORGANISM]". The terms "Colon cancer" and "Rectal cancer" were also used. In addition, the search for "Whole blood"[Sample Source] AND Homo sapiens [ORGANISM]" was used to retrieve datasets in the same database, thereby generating a pool serving as a comparison set to highlight CRC-specific differential gene expression compared to blood cells. The searches were carried out until February 2012. Search results were then filtered using inclusion and exclusion criteria as explained below.

The inclusion criteria of datasets in the analysis were: experiments of the type "Expression profiling by microarray"; primary tissue; any age or sex of the subject; cancer of any stage (for CRC); unfractioned peripheral blood; unstimulated blood cells; availability of the raw or pre-processed data for the single channel of the tissue of interest in the case of two-channel experiments.

Exclusion criteria were: cell line samples; non malignant adenoma tissues; metastatic cells; patients on treatment; cord blood; blood fractions, e.g. peripheral blood mononuclear cells or blood samples subjected to globin mRNA reduction; blood from treated or nonhealthy or paediatric subjects; exon arrays (hampering data elaboration by TRAM due to an exceedingly high number of data rows) or platforms using probes split into several distinct arrays for each sample (hampering intrasample normalization); platforms assaying an atypical number of genes (i.e. $<5.000$ or $>60.000$ ).

In order to obtain a quantitative transcriptome map, values from each dataset were linearized when provided as logarithms.

Finally, due to the timing of the TRAM elaboration process, for each series of GEO samples we randomly selected the first 10 listed samples when the sample number was greater than 10 . This was done for a total of 349 CRC samples out of 2,532 found and 200 samples of normal blood out of 958 found.

The 349 CRC subjects considered for our metaanalysis were randomly selected from 37 studies performed in different countries (Australia, China, Denmark, Finland, Germany, Hungary, Italy, Japan, Norway, Poland, Singapore, South Korea, Spain, USA). 
Their clinical data are not completely available for all subjects, and the age range of patients was between 42 and 88 years old. Males and females were equally represented, all colon sites and Dukes stages were included. The 200 blood samples considered were obtained from 23 studies, which were also from different countries (Australia, China, Denmark, Germany, India, Italy, Netherlands, Norway, United Kingdom, USA), and came from healthy subjects with no clinical history of neoplastic disease.

\section{TRAM (Transcriptome Mapper) analysis}

TRAM (Transcriptome Mapper) software allows the import of gene expression data recorded in the NCBI GEO database in tab-delimited text format. It also allows the integration of all data by decoding probe set identifiers to gene symbols via UniGene data parsing, normalizing data from multiple platforms using intra-sample and intersample normalization (scaled quantile normalization) [36].

We created a directory (folder) for each tissue, containing all the sample datasets related to the same source (pool 'A', CRC, $n=349$; pool 'B', blood, $n=200$ ) and selected for the study. The comparisons allowed us to analyse the differential transcriptome maps ' $A$ ' vs ' $B$ ', using the ratio of the mean expression values for each locus.

We used an updated version of TRAM, including enhanced resolution of gene identifiers and updated UniGene and Entrez Gene databases (TRAM 1.1, June 2013, freely available at http://apollo11.isto.unibo.it/ software), instead of the original 2011 version. The data for 10 platforms used by some of the experiments selected but not provided by the default configuration of TRAM 1.1 (version for "Human") were then uploaded (GPL80, GPL1449, GPL2006, GPL2895, GPL3121, GPL4811, GPL6370, GPL6883, GPL8432, GPL10665). In briefly, gene expression values were assigned to individual loci via UniGene, intra-sample normalized as a percentage of the mean value and inter-sample normalized by scaled quantile.

\section{Patients}

In order to evaluate the proper number of subjects to question, we performed the analysis of statistical power of the study with the G*Power 3 software for Macintosh OS X system. The sample size needed to achieve a power of 0.80 when analysing results by $t$-test (two-tails) has been estimated to be at least 64 healthy control subjects and 64 patients with diagnosed CRC (for alpha (Type I) error $=0.05$ and assuming a medium effect size at $d=0.5)$.

The study was conducted following approval by the ethical committee of Sant'Orsola-Malpighi Hospital, Bologna, and complied with the Ethical Principles for Medical Research Involving Human Subjects of the Helsinki Declaration. All subjects involved were asked for informed written consent before taking part in the study.
A peripheral blood sample $(5 \mathrm{~mL})$ was obtained from 67 healthy donors with no clinical history of neoplastic disease and from 67 unrelated patients with a histological confirmed diagnosis of CRC at any stage, before elective surgery (the patients' main clinical data are summarized in Table 3) and without any chemo or radio adjuvant treatments to the surgery. To reduce contamination of samples with epithelial cells from the needle stick, the first $1 \mathrm{~mL}$ of blood was discarded. The family history was determined by questioning each volunteer through a questionnaire they were requested to fill in at the time of the blood withdrawal.

\section{RNA Extraction}

The whole blood, drawn into an EDTA tube, was treated for lysis within one hour of being collected by adding TRIzol LS reagent (Invitrogen, Carlsbad, CA, USA) and total RNA was extracted according to the manufacturer's protocol. Total extracted RNA from $1 \mathrm{~mL}$ of blood was subjected to standard ethanol precipitation, and the pellet was dissolved in $15 \mu \mathrm{L}$ RNase-free water to a final concentration of up to $0.5 \mu \mathrm{g} / \mu \mathrm{L}$, and stored at $-20^{\circ} \mathrm{C}$.

The concentration of all RNA samples was quantified by Nanodrop ND-2000 spectrophotomer (Thermo Fisher Scientific, Waltham, MA).

\section{qRT-PCR}

$300 \mathrm{ng}$ of RNA was reverse transcribed with the RevertAid First Strand cDNA Synthesis kit (Carlo Erba Reagents, Milan, Italy) and amplified using the EvaGreen system (Bio-Rad, Hercules, CA), according to the manufacturer's instructions. The list of primers (SIGMA ALDRICH, Milan, Italy) for candidate markers and the reference gene is reported in Table 4.

Real-time PCR reactions were performed using the CFX96 instrument (Bio-Rad, Hercules, CA), in duplicate, at $95^{\circ} \mathrm{C}$ for $10 \mathrm{~min}$, followed by 40 cycles of $95^{\circ} \mathrm{C}$ for $15 \mathrm{sec}$ and $60^{\circ} \mathrm{C}$ for $1 \mathrm{~min}$, with melting curve analysis. Each qPCR run always included a negative control lacking cDNA template, and a positive control of cDNA derived from the HT-29 cell line, in which the gene of interest is known to be present. Reaction efficiency (E) was calculated from the slope of the standard curve generated from 10-fold serial dilutions of calibrator cDNA, according to the formula: $\mathrm{E}=[10(-1 /$ slope $)-1] \times 100$.

\section{Statistical analysis}

The Student's $t$-test was adopted for the comparison of the expression levels analysed between CRC cases and controls. ROC (Receiving Operating Characteristic) curve analysis was used to assess the accuracy with which the parameters diagnosed CRC, in order to discriminate between patients with CRC 
Table 3: Patients and control group information

\begin{tabular}{|c|c|c|c|c|}
\hline & & Cases & Controls & $P$ value \\
\hline & age & $68 \pm 12$ & $65 \pm 14$ & 0.40 \\
\hline \multirow[t]{2}{*}{ Gender } & male & 34 & 35 & 0.42 \\
\hline & female & 33 & 32 & \\
\hline \multirow[t]{4}{*}{ Grading } & G1 & 6 & - & \\
\hline & G2 & 45 & - & \\
\hline & G3 & 9 & - & \\
\hline & $*$ N.D.A. & 7 & - & \\
\hline \multirow[t]{6}{*}{ Position } & Cecum & 3 & - & \\
\hline & Ascending $\mathrm{c}$. & 17 & - & \\
\hline & Transverse c. & 3 & - & \\
\hline & Descending c. & 15 & - & \\
\hline & Sigmoid c. & 10 & - & \\
\hline & Rectum & 19 & - & \\
\hline \multirow[t]{10}{*}{ TNM } & T1N0 & 13 & - & \\
\hline & T2N0 & 15 & - & \\
\hline & T2N1 & 3 & - & \\
\hline & T3N0 & 13 & - & \\
\hline & T3N1 & 8 & - & \\
\hline & T3N2 & 6 & - & \\
\hline & T4N0 & 3 & - & \\
\hline & T4N1 & 1 & & \\
\hline & T4N2 & 2 & - & \\
\hline & *N.D.A. & 3 & - & \\
\hline \multirow[t]{4}{*}{ Dukes } & A & 28 & - & \\
\hline & B & 14 & - & \\
\hline & $\mathrm{C}$ & 19 & - & \\
\hline & $*$ N.D.A. & 6 & - & \\
\hline \multirow[t]{4}{*}{ STAGE } & 1 & 25 & - & \\
\hline & $2 \mathrm{~A} / \mathrm{B}$ & 15 & - & \\
\hline & $3 \mathrm{~A} / \mathrm{B} / \mathrm{C}$ & 18 & - & \\
\hline & *N.D.A. & 9 & - & \\
\hline \multirow[t]{3}{*}{ BMI } & $\leq 25$ & 26 & - & \\
\hline & $>25$ & 32 & - & \\
\hline & *N.D.A. & 9 & - & \\
\hline \multirow[t]{4}{*}{ Smoking History } & No Smokers & 35 & - & \\
\hline & Smokers & 8 & - & \\
\hline & Ex Smokers & 22 & - & \\
\hline & *N.D.A. & 2 & - & \\
\hline \multirow[t]{3}{*}{ Family History } & No Familiarity & 56 & - & \\
\hline & Familiarity & 8 & - & \\
\hline & *N.D.A. & 3 & - & \\
\hline
\end{tabular}

*N.D.A. No data available. 
Table 4: Primers used for RT-PCR

\begin{tabular}{|c|c|c|c|c|}
\hline Gene Symbol & Gene Name & $\begin{array}{l}\text { RefSeq RNA } \\
\text { GenBank } \\
\text { Accession No. }\end{array}$ & $\begin{array}{l}\text { Primer pairs sequence } \\
\left(5^{\prime} \rightarrow 3^{\prime}\right)_{a}\end{array}$ & $\begin{array}{l}\text { RT-PCR } \\
\text { product } \\
\text { size (base pair) }\end{array}$ \\
\hline TSPAN8 & Tetraspanin 8 & NM_004616 & $\begin{array}{l}\text { ctaagtctgatcgcattgtg } \\
\text { aacacaattatggcttcctg }\end{array}$ & 103 \\
\hline EPCAM & Epithelial cell adhesion molecule & NM_002354 & $\begin{array}{l}\text { gtatgagaaggctgagataaag } \\
\text { cttcaaagatgtcttcgtcc }\end{array}$ & 147 \\
\hline SPINK1 & $\begin{array}{l}\text { Serine peptidase inhibitor, Kazal } \\
\text { type } 1\end{array}$ & NM_003122 & $\begin{array}{l}\text { tgaaaatcggaaacgccagac } \\
\text { gcggtgacctgatgggattt }\end{array}$ & 89 \\
\hline COL1A2 & Collagen, type I, alpha 2 & NM_000089 & $\begin{array}{l}\text { gtggttactactggattgac } \\
\text { ctgccagcattgatagtttc }\end{array}$ & 184 \\
\hline $\mathrm{CDH1}$ & $\begin{array}{l}\text { Homo sapiens cadherin } 1 \text {, type } \\
1, \text { E-cadherin }\end{array}$ & NM_004360 & $\begin{array}{l}\text { cagtacaacgacccaaccca } \\
\text { cacgctgacctctaaggtgg }\end{array}$ & 99 \\
\hline$L G A L S 4$ & $\begin{array}{l}\text { Lectin, galactoside-binding, } \\
\text { soluble, } 4\end{array}$ & NM_006149 & $\begin{array}{l}\text { ttaccetggtcccggacatt } \\
\text { agcetcccgaaatatggcac }\end{array}$ & 135 \\
\hline CEACAM6 & $\begin{array}{l}\text { Carcinoembryonic antigen-related } \\
\text { adhesion molecule } 6\end{array}$ & NM_00248 & $\begin{array}{l}\text { cacagtctctggaagtgctcc } \\
\text { ggccagcactccaatcgt }\end{array}$ & 99 \\
\hline$B 2 M$ & Beta-2-microblobulin & NM_004048 & $\begin{array}{l}\text { tgcctgccgtgtgaaccatgt } \\
\text { tgcggcatcttcaaacctccatga }\end{array}$ & 97 \\
\hline
\end{tabular}

a Top: forward primer; bottom: reverse primer (for each gene).

and controls. Calculation of both the area under the curve and the corresponding 95\% confidence intervals was evaluated using MedCalc version 16 for statistical analyses. To determine the cut off of the markers that allows for the best discrimination between the two groups, the discriminant analysis was performed using SPSS statistical software, version 23. The sets of healthy and cancer patients were considered as grouping variable and the four independent markers grouped together as predicted variable for the panel.

\section{ACKNOWLEDGMENTS AND FUNDING}

This study was supported by grants from the "Fondazione Enzo Piccinini" (Modena, Italy) and the "Fondazione del Monte di Bologna e di Ravenna" (Bologna, Italy).

The authors are grateful to Dr. Danielle Marylin Mitzman for her assistance in the English language review.

\section{CONFLICTS OF INTEREST}

Authors declare no competing interest.

All authors have read the journal's authorship agreement and the manuscript has been reviewed and approved by all named authors.

\section{REFERENCES}

1. Bujanda L, Sarasqueta C, Hijona E, Hijona L, Cosme A, Gil I, Elorza JL, Asensio JI, Larburu S, Enríquez-
Navascués JM, Jover R, Balaguer F, Llor X et al. Colorectal cancer prognosis twenty years later. World journal of gastroenterology. 2010; 16:862-7.

2. Bujanda L, Sarasqueta C, Cosme A, Hijona E, EnriquezNavascues JM, Placer C, Villarreal E, Herreros-Villanueva M, Giraldez MD, Gironella M, Balaguer F, Castells A. Evaluation of alpha 1-antitrypsin and the levels of mRNA expression of matrix metalloproteinase 7 , urokinase type plasminogen activator receptor and COX-2 for the diagnosis of colorectal cancer. PloS one. 2013; 8:e51810.

3. Winawer S, Fletcher R, Rex D, Bond J, Burt R, Ferrucci J, Ganiats T, Levin T, Woolf S, Johnson D, Kirk L, Litin S, Simmang C, et al. Colorectal cancer screening and surveillance: clinical guidelines and rationale-Update based on new evidence. Gastroenterology. 2003; 124:544-60.

4. Vogelstein B, Fearon ER, Hamilton SR, Kern SE, Preisinger AC, Leppert M, Nakamura Y, White R, Smits AM, Bos JL. Genetic alterations during colorectaltumor development. The New England journal of medicine. 1988; 319:525-32.

5. Etzioni R, Urban N, Ramsey S, McIntosh M, Schwartz S, Reid B, Radich J, Anderson G, Hartwell L. The case for early detection. Nature reviews Cancer. 2003; 3:243-52.

6. Ganepola GA, Nizin J, Rutledge JR, Chang DH. Use of blood-based biomarkers for early diagnosis and surveillance of colorectal cancer. World journal of gastrointestinal oncology. 2014; 6:83-97.

7. Fung KY, Nice E, Priebe I, Belobrajdic D, Phatak A, Purins L, Tabor B1, Pompeia C1, Lockett T1, Adams TE1, 
Burgess A1, Cosgrove L1. Colorectal cancer biomarkers: to be or not to be? Cautionary tales from a road well travelled. World journal of gastroenterology. 2014; 20:888-98.

8. Rengucci C, Maio GD, Menghi M, Scarpi E, Guglielmo S, Fusaroli P, Caletti G, Saragoni L, Gardini AC, Zoli W, Falcini F, Amadori D, Calistri D. Improved Stool DNA Integrity Method for Early Colorectal Cancer Diagnosis. Cancer epidemiology, biomarkers \& prevention. 2014; 23:2553-60. doi: 10.1158/1055-9965.EPI-14-0379.

9. Imperiale $\mathrm{TF}$, Ransohoff DF, Itzkowitz SH, Levin TR, Lavin P, Lidgard GP, Ahlquist DA, Berger BM. Multitarget stool DNA testing for colorectal-cancer screening. The New England journal of medicine. 2014; 370:1287-97.

10. Robertson DJ, Dominitz JA. Stool DNA and colorectalcancer screening. The New England journal of medicine. 2014; 370:1350-1.

11. Cristofanilli M, Hayes DF, Budd GT, Ellis MJ, Stopeck A, Reuben JM, Doyle GV, Matera J, Allard WJ, Miller MC, Fritsche HA, Hortobagyi GN, Terstappen LW. Circulating tumor cells: a novel prognostic factor for newly diagnosed metastatic breast cancer. Journal of clinical oncology. 2005; 23:1420-30.

12. Cohen SJ, Punt CJ, Iannotti N, Saidman BH, Sabbath KD, Gabrail NY, Picus J, Morse M, Mitchell E, Miller MC, Doyle GV, Tissing H, Terstappen LWMM, Me, et al. Relationship of circulating tumor cells to tumor response, progression-free survival, and overall survival in patients with metastatic colorectal cancer. Journal of clinical oncology. 2008; 26:3213-21.

13. Marshall KW, Mohr S, Khettabi FE, Nossova N, Chao S, Bao W, Ma J, Li XJ, Liew CC. A blood-based biomarker panel for stratifying current risk for colorectal cancer. International journal of cancer. 2010; 126:1177-86.

14. Novak DJ, Liew GJ, Liew CC. GeneNews Limited: bringing the blood transcriptome to personalized medicine. Pharmacogenomics. 2012; 13:381-5.

15. Bettegowda C, Sausen M, Leary RJ, Kinde I, Wang Y, Agrawal N, Bartlett BR, Wang H, Luber B, Alani RM, Antonarakis ES, Azad NS, Bardelli A, et al. Detection of circulating tumor DNA in early- and late-stage human malignancies. Science translational medicine. 2014; 6:224ra24.

16. Paterlini-Brechot $\mathrm{P}$, Benali NL. Circulating tumor cells (CTC) detection: clinical impact and future directions. Cancer letters. 2007; 253:180-204.

17. Langan RC, Mullinax JE, Raiji MT, Upham T, Summers T, Stojadinovic A, Avital I. Colorectal cancer biomarkers and the potential role of cancer stem cells. Journal of Cancer. 2013; 4:241-50.

18. Schwarzenbach $\mathrm{H}$. Circulating nucleic acids as biomarkers in breast cancer. Breast cancer research. 2013; 15:211.

19. Barbazan J, Muinelo-Romay L, Vieito M, Candamio S, Diaz-Lopez A, Cano A, Gómez-Tato A, Casares de Cal Mde L, Abal M, López-López R. A multimarker panel for circulating tumor cells detection predicts patient outcome and therapy response in metastatic colorectal cancer. International journal of cancer. 2014; 135:2633-43.

20. Barbazan J, Vieito M, Abalo A, Alonso-Alconada L, Muinelo-Romay L, Alonso-Nocelo M, León L, Candamio S, Gallardo E, Anido U, Doll A, de los Ángeles Casares M, Gómez-Tato A, et al. A logistic model for the detection of circulating tumour cells in human metastatic colorectal cancer. Journal of cellular and molecular medicine. 2012; $16: 2342-9$.

21. Gervasoni A, Monasterio Munoz RM, Wengler GS, Rizzi A, Zaniboni A, Parolini O. Molecular signature detection of circulating tumor cells using a panel of selected genes. Cancer letters. 2008; 263:267-79.

22. Lagoudianakis EE, Kataki A, Manouras A, Memos N, Papadima A, Derventzi A, Zografos G, Papadopoulos S, Katergiannakis V, Konstadoulakis MM. Detection of epithelial cells by RT-PCR targeting CEA, CK20, and TEM-8 in colorectal carcinoma patients using OncoQuick density gradient centrifugation system. The Journal of surgical research. 2009; 155:183-90.

23. Gonzalez-Masia JA, Garcia-Olmo D, Garcia-Olmo DC. Circulating nucleic acids in plasma and serum (CNAPS): applications in oncology. OncoTargets and therapy. 2013; 6:819-32.

24. Kopreski MS, Benko FA, Kwak LW, Gocke CD. Detection of tumor messenger RNA in the serum of patients with malignant melanoma. Clinical cancer research 1999; 5:1961-5.

25. Ng EK, Tsui NB, Lam NY, Chiu RW, Yu SC, Wong SC, Lo ES, Rainer TH, Johnson PJ, Lo YM. Presence of filterable and nonfilterable mRNA in the plasma of cancer patients and healthy individuals. Clinical chemistry. 2002; 48:1212-7.

26. De Maio G, Rengucci C, Zoli W, Calistri D. Circulating and stool nucleic acid analysis for colorectal cancer diagnosis. World journal of gastroenterology. 2014; 20:957-67.

27. Smirnov DA, Zweitzig DR, Foulk BW, Miller MC, Doyle GV, Pienta KJ, Meropol NJ, Weiner LM, Cohen SJ, Moreno JG, Connelly MC, Terstappen LW, O'Hara SM. Global gene expression profiling of circulating tumor cells. Cancer research. 2005; 65:4993-7.

28. Bustin SA, Mueller R. Real-time reverse transcription PCR and the detection of occult disease in colorectal cancer. Molecular aspects of medicine. 2006; 27:192-223.

29. Lauriola M, Ugolini G, Rosati G, Zanotti S, Montroni I, Manaresi A, Zattoni D, Rivetti S, Mattei G, Coppola D, Strippoli P, Taffurelli M, Solmi R. Identification by a Digital Gene Expression Displayer (DGED) and test by RT-PCR analysis of new mRNA candidate markers for colorectal cancer in peripheral blood. International journal of oncology. 2010; 37:519-25.

30. Solmi R, Lauriola M, Francesconi M, Martini D, Voltattorni M, Ceccarelli C, Ugolini G, Rosati G, Zanotti S, Montroni I, Mattei G, Taffurelli M, Santini D, et al. 
Displayed correlation between gene expression profiles and submicroscopic alterations in response to cetuximab, gefitinib and EGF in human colon cancer cell lines. BMC cancer. 2008; 8:227.

31. Solmi R, Ugolini G, Rosati G, Zanotti S, Lauriola M, Montroni I, del Governatore M, Caira A, Taffurelli M, Santini D, Coppola D, Guidotti L, Carinci P, et al. Microarray-based identification and RT-PCR test screening for epithelial-specific mRNAs in peripheral blood of patients with colon cancer. BMC cancer. 2006; 6:250.

32. Findeisen P, Rockel M, Nees M, Roder C, Kienle P, Von Knebel Doeberitz M, Kalthoff H, Neumaier M. Systematic identification and validation of candidate genes for detection of circulating tumor cells in peripheral blood specimens of colorectal cancer patients. International journal of oncology. 2008; 33:1001-10.

33. Solmi R, De Sanctis P, Zucchini C, Ugolini G, Rosati G, Del Governatore M, Coppola D, Yeatman TJ, Lenzi L, Caira A, Zanotti S, Taffurelli M, Carinci P et al. Search for epithelialspecific mRNAs in peripheral blood of patients with colon cancer by RT-PCR. International journal of oncology. 2004; 25:1049-56.

34. Lenzi L, Facchin F, Piva F, Giulietti M, Pelleri MC, Frabetti F, Vitale L, Casadei R, Canaider S, Bortoluzzi S, Coppe A, Danieli GA, Principato G et al. TRAM (Transcriptome Mapper): database-driven creation and analysis of transcriptome maps from multiple sources. BMC genomics. 2011; 12:121.

35. Piovesan A, Vitale L, Pelleri MC, Strippoli P. Universal tight correlation of codon bias and pool of RNA codons (codonome): The genome is optimized to allow any distribution of gene expression values in the transcriptome from bacteria to humans. Genomics. 2013; 101:282-9.

36. Caracausi M, Vitale L, Pelleri MC, Piovesan A, Bruno S, Strippoli P. A quantitative transcriptome reference map of the normal human brain. Neurogenetics. 2014; 15:267-87.

37. Fleischhacker M, Schmidt B. Circulating nucleic acids (CNAs) and cancer-a survey. Biochimica et biophysica acta. 2007; 1775:181-232.

38. Hamm A, Prenen H, Van Delm W, Di Matteo M, Wenes M, Delamarre E, Schmidt T, Weitz J, Sarmiento R, Dezi A, Gasparini G, Rothé F, Schmitz R, et al. Tumour-educated circulating monocytes are powerful candidate biomarkers for diagnosis and disease follow-up of colorectal cancer. Gut. 2015. doi: 10.1136/gutjnl-2014-308988

39. Schwarzenbach H, Hoon DS, Pantel K. Cell-free nucleic acids as biomarkers in cancer patients. Nature reviews Cancer. 2011; 11:426-37.

40. Tsui NB, Ng EK, Lo YM. Stability of endogenous and added RNA in blood specimens, serum, and plasma. Clinical chemistry. 2002; 48:1647-53.
41. Imperiale TF, Ransohoff DF, Itzkowitz SH. Multitarget stool DNA testing for colorectal-cancer screening. The New England journal of medicine. 2014; 371:187-8.

42. Berthier-Vergnes $\mathrm{O}$, Kharbili ME, de la Fouchardiere A, Pointecouteau T, Verrando P, Wierinckx A, Lachuer J, Le Naour F, Lamartine J. Gene expression profiles of human melanoma cells with different invasive potential reveal TSPAN8 as a novel mediator of invasion. British journal of cancer. 2011; 104:155-65.

43. Duxbury MS, Ito H, Benoit E, Waseem T, Ashley SW, Whang EE. A novel role for carcinoembryonic antigenrelated cell adhesion molecule 6 as a determinant of gemcitabine chemoresistance in pancreatic adenocarcinoma cells. Cancer research. 2004; 64:3987-93.

44. Jantscheff P, Terracciano L, Lowy A, Glatz-Krieger K, Grunert F, Micheel B, Brümmer J, Laffer U, Metzger U, Herrmann R, Rochlitz C. Expression of CEACAM6 in resectable colorectal cancer: a factor of independent prognostic significance. Journal of clinical oncology. 2003; 21:3638-46.

45. Bode MK, Karttunen TJ, Makela J, Risteli L, Risteli J. Type I and III collagens in human colon cancer and diverticulosis. Scandinavian journal of gastroenterology. 2000; 35:747-52.

46. Zou X, Feng B, Dong T, Yan G, Tan B, Shen H, Huang A2, Zhang X1, Zhang M4, Yang P3, Zheng M2, Zhang Y5. Up-regulation of type I collagen during tumorigenesis of colorectal cancer revealed by quantitative proteomic analysis. Journal of proteomics. 2013; 94:473-85.

47. Satelli A, Rao PS, Thirumala S, Rao US. Galectin-4 functions as a tumor suppressor of human colorectal cancer. International journal of cancer. 2011; 129:799-809.

48. Rechreche H, Mallo GV, Montalto G, Dagorn JC, Iovanna JL. Cloning and expression of the mRNA of human galectin-4, an S-type lectin down-regulated in colorectal cancer. European journal of biochemistry. 1997; 248:225-30.

49. Winegarden N. Microarrays in cancer: moving from hype to clinical reality. Lancet. 2003; 362(9394):1428.

50. Fukino K, Shen L, Patocs A, Mutter GL, Eng C. Genomic instability within tumor stroma and clinicopathological characteristics of sporadic primary invasive breast carcinoma. Jama. 2007; 297:2103-11.

51. Patocs A, Zhang L, Xu Y, Weber F, Caldes T, Mutter GL, Platzer P, Eng C. Breast-cancer stromal cells with TP53 mutations and nodal metastases. The New England journal of medicine. 2007; 357:2543-51. 